\title{
THE ASSOCIATION BETWEEN SERUM BETA- HUMAN CHORIONIC GONADOTROPIN AND PREECLAMPSIA
}

\author{
BEGUM $Z^{1}$, ARA I ${ }^{2}$, TANIRA $\mathrm{S}^{3}$, KEYA KA ${ }^{4}$

\begin{abstract}
:
Background: Exact aetiology of this potentially fatal disorder remains poorly understood. A number of theories have been put forward where different biochemical markers have been implicated in the causal association of preeclampsia. This study was intended to find the association between serum $\beta$ - $h$ CG level and preclampsia
\end{abstract}

Methods: This cross-sectional, case-control study was conducted on 74 pregnant women with preeclampsia (cases) who were admitted in the Eclampsia ward of Dhaka Medical College Hospital, Dhaka between January and July of 2013. A total of 76 normotensive pregnant women were also taken from the Obstetrics \& Gynaecology Out-patient Department of the same hospital as control. The study subjects were selected on the basis of predefined eligibility criteria. The serum levels of $\beta$-hCG were compared between case and control groups as well as between mild and severe preeclampsia.

Result: The case and control groups were almost similar in terms of all the baseline demographic and obstetric characteristics except past history of PET which was significantly higher in the former group than that in the latter group. Majority (97.1\%) of the cases had severe hypertension (74.3\%) with mean systolic and diastolic blood pressures being 162.6 and $110.8 \mathrm{mmHg}$ respectively. The mean serum $\beta$-hCG was much higher in the case group than that in the control group ( $p<0.001)$. The mean serum $\beta-h C G$ was the highest in severe preeclampsia and the lowest in the control group, while that in mild preeclampsia lie in between the two $(p<0.001)$. The serum $\beta$-hCG exhibits a significantly linear correlation with systolic and diastolic blood pressures $(p<0.001$ respectively).

Conclusion: There was a significant difference between the $\beta$-hCG level in the preeclamptic women compared to the normotensive pregnant women and the severity of preeclamsia increases with further rise of $\beta$ - $h$ CG level.

Key words: preeclampsia, serum $\beta$-hCG.

J Dhaka Med Coll. 2014; 23(1) : 89-93.

\section{Introduction:}

Preeclampsia is a relatively common syndrome, dangerous for mother and infant, unpredictable in its onset and progression and untreatable except through termination of the pregnancy ${ }^{1}$. It affects up to $7 \%$ of pregnant women and is considered a leading cause of fetal growth restriction and perinatal morbidity and mortality. Despite many active researches for years, the exact aetiology of this potentially fatal disorder remains poorly understood. A number of theories have been put forward where different biochemical markers have been implicated in the causal association of preeclampsia. Several studies have reported an association between unexplained increases in maternal serum $\beta$-hCG levels in the second trimester of pregnancy and subsequent development of preeclampsia. ${ }^{2}$

Human $\beta$-hCG is a glycoprotein with lipid structure that is expressed in trophoblast and various malignant tumors. Human placenta

1. Dr. Zinat Begum, Assistant Professor, Department of Obstetrics \& Gynaecology, Dhaka Medical College, Dhaka.

2. Dr. Iffat Ara, Professor, Department of Obstetrics \& Gynaecology, Dhaka Medical College, Dhaka.

3. Dr. Shaorin Tanira, Assistant Director (Health), MCH-FP Clinic, Manabik Shahajya Sangstha (MSS), Dhaka.

4. Dr. Kashfia Ahmed Keya, Medical Officer, Department of Obstetrics \& Gynaecology, Bangabandhu Sheikh Mujib Medical University (BSMMU), Dhaka.

Correspondence: Dr. Zinat Begum, Assistant Professor, Department of Obstetrics \& Gynaecology, Dhaka Medical College, Dhaka. 
synthesizes steroid, protein, and glycoprotein hormones throughout gestation ${ }^{3}$. The production of hCG by the placenta in early pregnancy is crucial for implantation and maintenance of the blastocyst. Since it is postulated that preeclampsia is a trophoblastic disorder ${ }^{4}$, it has become essential to understand this disease, to investigate the pathologic and secretory reaction of the placenta. Twin pregnancies ${ }^{5}$ and molar pregnancies ${ }^{6}$ produce higher levels of hCG and they are associated with a higher incidence of preeclampsia than uncomplicated singleton pregnancies. An association has been reported between preeclampsia and elevated third trimester hCG levels ${ }^{2}$. Considerable evidence suggests an association between serum hCG levels and preclampsia ${ }^{7-12}$. Physiological concentrations of hCG is significantly increased in vitro capillary formation and migration of endothelial cells in a dosedependant manner and has a novel function in ueterine adaptation to early pregnancy ${ }^{13}$.

As the possible role hCG in the pathophysiology of preeclampsia is not well-understood and changes in its level can reflect the placental reaction to preeclampsia, we are encouraged to determine the association between serum â-hCG level and preclampsia after 20 weeks of pregnancy.

\section{Methods:}

In this cross-sectional case-control study, a total 74 pregnant women with preeclampsia who were admitted in the Eclampsia Ward of Dhaka Medical College Hospital, Dhaka, between January and July of 2013, were included in this study. Singleton pregnant women free from diabetes or trophoblastic disease or any other chronic disease were the criteria for inclusion in the study. Pregnant women with smoking habit were excluded from the study. A total of 76 normotensive pregnant women were taken from the Obstetrics \& Gynaecology Out-patient Department of same hospital as control. Subjects of the two groups were compared for their baseline characteristics (age, socioeconomic status, BMI and gestational age). The criteria for severe preeclampsia were systolic blood pressure $>160$
$\mathrm{mmHg}$ and diastolic blood pressure $>110 \mathrm{mmHg}$ and proteinuria $>5 \mathrm{~g}$ in 24 hours. In addition, any pregnant women with oliguria (urine output $<30 \mathrm{ml}$ per hour), cerebral or visual disturbance, epigastric pain, pulmonary oedema or abnormal platelet count or liver function profile was considered as severe preeclampsia. Subjects on inclusion into the study were tested for serum â-hCG. Serum levels of â-hCG were measured by immunochemistry (Imulite 1000, USA) and were compared between groups.

Statistical analysis was performed using Chisquare or Fisher's Exact Probability Test and Student's t-Test. Correlation between serum â-hCG and blood pressures were studied to see whether the two variables exhibit any linear correlation. The level of significance was set at 0.05 and $p<0.05$ was considered significant.

\section{Result:}

The case and control groups were almost similar in terms of age with mean age of the former and the latter groups being 23.3 and 24.3 years respectively $(p=0.342)$. The groups were also identical with respect to their socioeconomic status $(p=0.430)$. and BMI $(p=0.291)$ (Table-I). Comparison of present and past obstetric history shows that there were no significant differences between the groups with respect to gestational age, gravida and or history abortion or MR ( $\mathrm{p}=0.328, \mathrm{p}=0.522$ and $\mathrm{p}=0.847$ ). However, the history of past PET was staggeringly higher in the case group compared to that in the control group ( $\mathrm{p}<0.001)$ (Table-II).

Distribution of clinical variables among cases showed that majority (97.1\%) of the cases had oedema and severe hypertension $(74.3 \%)$ with mean systolic and diastolic blood pressures being 162.6 and $110.8 \mathrm{mmHg}$ respectively. Over half $(53.4 \%)$ of the cases had moderate proteinuria and $45.2 \%$ severe proteinuria (Table-III). The mean serum â-hCG was unusually higher in the case group than that in the control group $(\mathrm{p}<0.001)$ (Table-IV).

Association between severity of preeclampsia and serum â-hCG shows that mean serum âhCG was the highest in severe preeclampsia and the lowest in the control group, while that in mild preeclampsia lie in between the two $(\mathrm{p}<0.001)($ Table-V). 
The Association Between Serum Beta-Human Chorionic Gonadotropin And Preeclampsia

Table-I

Comparison of demographics and anthropometric variables between groups

\begin{tabular}{lccc}
\hline Demographics and anthropometric variables & \multicolumn{2}{c}{ Group } & P value \\
& Case $(\mathrm{n}=74)$ & Control(n=76) & \\
\hline Age (years) & $23.3 \pm 6.7$ & $24.3 \pm 5.2$ & 0.342 \\
Socioeconomic status & & & \\
Lower & $37(50.0)$ & $39(52.7)$ & 0.430 \\
Middle class & $26(35.1)$ & $29(39.2)$ & \\
Rich & $11(14.9)$ & $6(8.1)$ & \\
BMI & $23.6 \pm 3.6$ & $22.9 \pm 2.6$ & 0.291 \\
\hline
\end{tabular}

Figures in the parentheses indicate corresponding \%; Data were analyzed using Unpaired Student's ' $t$ ' test and were presented as mean $\pm \mathrm{SD}$. Chi-squared Test $\left(\chi^{2}\right)$ was done to analyze the data.

Table II

Comparison of obstetrical variables between groups

\begin{tabular}{lccc}
\hline Obstetrical variables & \multicolumn{2}{c}{ Group } & P \\
& Case $(\mathrm{n}=74)$ & Control $(\mathrm{n}=76)$ & value \\
\hline Gestational age in weeks & $33.3 \pm 3.6$ & $32.7 \pm 4.2$ & 0.328 \\
Gravida* & & & \\
Primigravida & $35(50.0)$ & $28(44.4)$ & 0.522 \\
Multigravida & $35(50.0)$ & $35(55.6)$ & \\
History of abortion/MR* & $16(23.5)$ & $20(26.3)$ & 0.847 \\
History of past PET* & $34(50.0)$ & $2(2.6)$ & $<0.001$ \\
\hline
\end{tabular}

Figures in the parentheses indicate corresponding \%; Data were analyzed using Unpaired Student's ' $t$ ' test and were presented as mean $\pm \mathrm{SD}$. Chi-squared Test $\left(\chi^{2}\right)$ was done to analyze the data.

Table-III

Distribution of cases by blood pressure and proteinuria

\begin{tabular}{lcc}
\hline Clinical variables & Frequency $(\%)$ & Mean \pm SD \\
\hline Oedema & $68(97.1)$ & - \\
Systolic BP & & $162.6 \pm 14.6$ \\
Mild (140-160 mmHg) & $19(25.7)$ & \\
Severe (e"160) mmHg) & $55(74.3)$ & $110.8 \pm 9.3$ \\
Diastolic BP & & \\
Mild (90-110 mmHg) & $12(16.2)$ & - \\
Severe (e"110 $\mathrm{mmHg})$ & $62(83.8)$ & - \\
Urine protein & & - \\
+ & $39(1.4)$ & - \\
++ & $33(45.4)$ & \\
+++ &
\end{tabular}


Table IV

Comparison of obstetrical variables between groups

\begin{tabular}{lccc}
\hline & & Group & \\
& Case $(\mathrm{n}=74)$ & Control $(\mathrm{n}=76)$ & value \\
\hline Serum $\chi$-hCG & $45439.6 \pm 5003.6$ & $4937.0 \pm 526.1$ & $<0.001$ \\
\hline
\end{tabular}

Data were analyzed using Unpaired Student's 't' test and were presented as mean \pm SEM.

Table V

Association between serum $\chi-h C G$ and severity of preeclampsia

\begin{tabular}{lcccc}
\hline & \multicolumn{3}{c}{ Group } & P \\
& $\begin{array}{c}\text { Severe preclamsia } \\
(\mathrm{n}=65)\end{array}$ & $\begin{array}{c}\text { Mild preeclampsia } \\
(\mathrm{n}=8)\end{array}$ & $\begin{array}{c}\text { Control } \\
(\mathrm{n}=76)\end{array}$ & value \\
\hline Serum $\chi$-hCG $(\mathrm{mlu} / \mathrm{ml})$ & $47576.6 \pm 4804.6$ & $43334.9 \pm 4894.3$ & $4937.0 \pm 456.4$ & $<0.001$ \\
\hline
\end{tabular}

Figures in the parentheses indicate corresponding \%; Data were analyzed using ANOVA statistics and were presented as mean $\pm \mathrm{SD}$.

\section{Discussion:}

The present study showed that mean level of serum â-hCG was significantly higher in preclamptic women than that in their control counterpart. The mean level of of â-hCG also tends to be significantly higher in severe preeclamptic women than that in mild preeclamptic and normotensive controls. Our results are in concordance with most of the previous reports ${ }^{14-18}$. However, it is in contrast with some other studies ${ }^{19,20}$. As an indirect evidence of relationship between $\hat{a}-\mathrm{hCG}$ and preclampsia, we studied the correlation between $\mathrm{a}-\mathrm{hCG}$ and blood pressure and found that the former parameter exhibits a linear correlation with systolic and diastolic blood pressures $(p<0.001)$ indicating that $25 \%$ of the rise in blood pressures could be explained by serum â-hCG. An even more pronounced relationship between the two variables was observed in a study, conducted in China on 142 normotensive and 43 preeclamptic women $(\mathrm{r}=$ $0.677, \mathrm{p}<0.05)$. The authors of the study concluded that the â-hCG level might reflect the degree of disordered activity of placental throphoblast in pregnancy induced hypertension (PIH) and could be utilized as a marker in determining $\mathrm{PIH}^{16}$. In another study, conducted on 32 women with PIH and 17 normotensive pregnant women, the relationship between Endothelin (ET) and hCG with preeclampsia was studied. The study concluded that ET and hCG are definitely higher in women with PIH than those in normotensive subjects. Therefore, their increases suggest a functional disorder in placental cells, which may result from damage to the endothelial cells ${ }^{17}$.

In an attempt to measure the Urinary Gonadotropin Peptide (UGP) (the urinary metabolite of the $\mathrm{hCG}$ ) in preeclamptic women, a case control study was conducted in Sweden in 1998. The study was carried out on 18 preeclamptic women and 20 normotensive pregnants in the third trimester of their pregnancy. A considerable increase in the UGP level was observed in preeclamptic patients than that in normotensive ones. These results suggest some placental hypoperfusion as a preeclamptic etiology ${ }^{21}$. A study conducted in Istanbul, Turkey, in 2004, compared â-hCG levels in 80 women suffering from mild preeclampsia, severe preeclampsia, superimposed hypertension and chronic hypertension with 25 normotensive pregnant women. The â-hCG level was reported to be $17000 \mathrm{mIu} / \mathrm{mL}$ in mild preeclamptic women, $49000 \mathrm{mIu} / \mathrm{mL}$ in severe preeclamptic women, about $41000 \mathrm{mIu} \mathrm{mL} / \mathrm{ml}$ in women with superimposed hypertension, $12558 \mathrm{mIu} / \mathrm{mL}$ in 
women with chronic hypertension and 9647 $\mathrm{mIu} / \mathrm{mL}$ in normotensive women. The results indicated that the â-hCG level in women with severe preeclampsia was significantly more than those in other groups $(\mathrm{p}<0.001)^{22}$.

The results of the present study showed that the â-hCG level in case of both mild and severe preeclampsia tends to increase due to disorder in the activity of placental cells leading to placental perfusion disorder and damaging to throphoblastic cells. Therefore, measuring the â-hCG level may help in the early diagnosis of the disease as well as may be an indicator of the severity of the disease.

\section{References:}

1. Redman CWG. Current topic: pre-eclampsia and the placenta. Placenta 1991; 12: 301-8.

2. Hsu CD, Chan DW, Iriye B, Johnson TRB, Hong S-F, Repke JT. Elevated serum human chorionic gonadotropin as evidence of secretory response in severe preeclampsia. Am J Obstet Gynecol 1994; 170: $1135-8$.

3. Petraglia F, Volpe A, Genazzani AR, Rivier J, Sawchenko PE, Vale W. Neuroendocrinology of the human placenta. Front Neuroendocrinol 1990; 11: 6-37.

4. Redman CWG. Platelets and the beginning of preeclampsia. N Engl J Med 1990; 323: 478-80.

5. Long PA, Oat JN. Preeclampsia in twin pregnancy: severity and pathogenesis. Aust NZ J Obstet Gynecol 1987; 27: 1-5.

6. Curry SL, Hammond CB, Tyrey L, Creasman WT, Parker RT. Hydatidiform mole: diagnosis, management, and long-term follow-up of 347 patients. Obstet Gynecol 1975; 45: 1-8.

7. Onderoglu LS, Kabukçu A. Elevated second trimester human chorionic gonadotropin level associated with adverse pregnancy outcome. Int J Obstet Gynecol 1997; 56: 245-9.

8. Smith GC, Smith OW. Excessive gonadostimulatory hormone and subnormal amounts of oestrin in toxaemia of late pregnancy. Am J Obstet Gynecol 1934; 107: 128-45.

9. Muller F, Savey L, Le Fiblek B, Bussieres L, Ndayizamba G, Colau JC, et al. Maternal serum human chorionic gonadotrpin level at fifteen weeks is a predictor for preeclampsia. Am J Obstet Gynecol 1996; 175: 37-9.

10. Said ME, Campell DM, Azzam ME, MacGillivray I. Beta-human chorionic gonadotropin levels before and after the development of pre-eclampsia. $\mathrm{Br} \mathrm{J}$ Obstet Gynaecol 1984; 91: 7872-5.

11. Adnan MN, Ashour MB, Ellice SL, Louise EWH, John TR. The value of elevated second-trimester â-human chorionic gonadotropin in predicting development of preeclampsia. Am J Obstet Gynecol 1997; 176: 438-42.

12. Anneli MP, Anna LH, Olli JV, Aimo OR, Timo JL. Midtrimester N-terminal proatrial. natriuretic peptide, free beta hCG, and alpha-fetoprotein in predicting Preeclampsia. Obstet Gynecol 1998; 91: 940-4.

13. Zygment MF, Herr S, Keller-Schoenwetter K, Kunzi-Rapp and Munstedt K. Characterization of human chorionic gonadotropin as a novel angiogenic factor. J Clin Endocrinol Metab 2002; 87: 5290-6.

14. Akbari S, Vahabi S, Khaksarian M. A Study of âHuman Chorionic Gonadotropin Level in Preeclamptic and Normotensive Pregnant Women. Res J Biol Sci 2009; 4(4): 468-71.

15. Basirat J, Barat S, Hajiahmadi M. Serum â-human chorionic gonadotropin levels and preeclampsia. Saudi Med J 2006; 27: 1001-04.

16. Feng Q, Cui S, Yang W. Clinical significance of beta-hCG and human placental lactogen in serum of normal pregnancies and patients with pregnancy induced hypertension [Article in Chinese] [Abstract]. Zhonghua Fu Chan Ke Za Zhi 2000; 35(11): 648-50.

17. Li Z, Lin H, Mai M. Levels of endothelin and beta human chorionic gonadotropin and their relationship in patients with pregnancy induced hypertension [Article in Chinese] [Abstract]. Zhonghua Fu Chan Ke Za Zhi 1998; 33(11): 661-3.

18. Ong CY, Liao AW, Spencer K, Munim S, Nicolaides KH. First trimester maternal serum free â-human chorionic gonadotropin and pregnancy associated plasma protein A as predictors of pregnancy complications. Br J Obstet Gynaecol 2000; 107: 1265-70.

19. Dugoff L, Hobbins JC, Malone FD, Porter TF, Luthy $\mathrm{D}$, Comstock $\mathrm{CH}$ et al. First trimester maternal serum PAPP-A and free â subunit human chorionic gonadotropin concentrations and nuchal translucency are associated with obstetric complications: A population-based screening study (the FASTER Trial). Am J Obstet Gynecol 2004; 191: 1446-51.

20. Tul N, Pusenjak S, Osredkar J, Spencer K, NovakAntolic Z. Predicting complications of pregnancy with $1^{\text {st }}$ trimester maternal serum free â-hCG, PAPP-A and inhibin-A. Prenat Diagn 2003; 23: 990-6.

21. Williams MA, Luthy DA, Zingheim RW, Zebelman AM, Sorensen TK, Resta RG. Urinary gondotropin peptide levels in preeclamptic and normotensive pregnant women: Result fro a pilot case-control study. Gynecol Obstet Invest 1998; 45: 24-8.

22. Gubuz A, Karateke A, Mengulluoglu M, Gedikbasi A, Ozturkmen M, Kabaca C et al. Can serum hCG values be used in the differential diagnosis pregnancy complicated by hypertension? Hypertens Pregnancy 2004; 23: 1-12. 